\title{
Finite Difference Time Domain Analysis of Two Dimensional Photonic Bandgap Devices

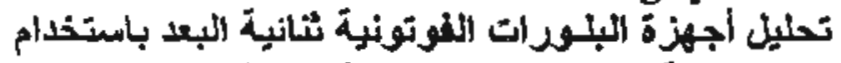

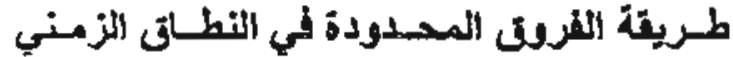

\section{Nihal F. Areed, Salah S. A. Obayya, and Hamdi A. El-Mikati}

Department of blectronice and t:Icetrioal Communicalions Fingincering Mansonrs Univeruily, Mansoura Egypt

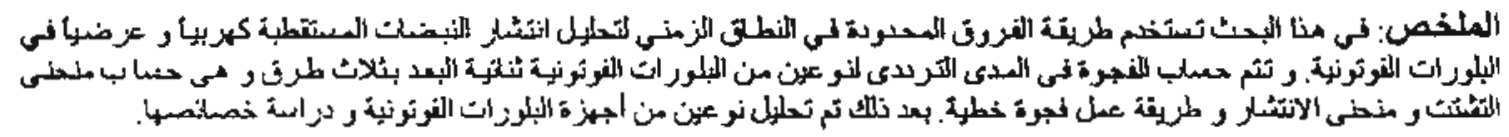

Abstract: A Finilc Differente Timc Domnin (FDTD) analysis has been effeclively applied to investigatc the transmission of the transverse cloctric polarized pulses in phoionic crystals arrangements. The photonic bandgap of 2-D photonic crystal with square and veins lattices has becn calculated using threc methods Band structure, transmission diagram and defoctod structures, and comparison with publishod results are done and excellent agreement are obtained. Moreover, two different pholonic crystal devices are analyzed

hidex Tems: Photonic Crystal [PC], Finite Diflerence Timc Domain (FDTD), Photonic Bandgap (PBG).

\section{Introduction}

Plawanic etysals (l'C's) ite perionlic dielectric or metallo-dielectric (manos)sucturs: that ace designed to alleet the propagation of electromagnetic waves (EM) in the sarte way as the periodic potential in a semiconductor crystal affects the electron motion by defuling allowed and forbidden electronic encrgy bands. The absence of allowed propagating EM mods inside the structures, in a range of wavelengths alled a photonic band gap, gives risc to distinct optical phenomena such as inhibition of spontancous emission, bigh-reflecting omidirectional mirrors and low-loss-wave guiding among others[!!

According to the number of directions in which dielectric materials exhibit periodicity, one, wo, or three dimensional photonic crystal structures are possible [2].

$\Lambda$ two dimensional system exhibits most of the important characteristics of photonic crystal structures. This type has a periodic geometry in two directions and homogeneous in the third. There are many lyjes of two! dimensional photoric crystal systems such as square, triangular, honeycomb and vcins laltices $[3-4]$ :

Rescurches over the last decade bave gencraled a wide range of rigorous numerical algorithms for modeling photonic crystal structures, such as plane-wave cxpansion (PWE) iul fitite tieurent methoxls [5]. These versalik algorilhms hnve been applice with sucess in study issucs such as dispersion relation ancl propagation charazteristics for PC structures.

In this paper, Finite Difference Timo Domain (FDTD) Technique has been utilized to calculate the photonic bandgap of $2 \mathrm{D} \mathrm{PCs}$ with diflerent tattice arangenents and to analyze two difterent byes of photonic batudgap devices.

This paper is organizod as follows Following this introduction, a brief mathematical trethent of [rD'D method is given in section II Methods of calculating PBG are given in section III. Section IV detailed the results and theij physical explanation. Finally, some conclusions are presented in section $\mathrm{V}$.

\section{Formulation}

\section{A-Bask Equations}

In a two-dimensional case, the field: can be docoupled into two Iransversely polarizal modes, namely the $\mathrm{E}$ polarization $\left(E_{r}, H_{x}\right.$, and $\left.H_{y}\right)$ and the $\mathrm{H}$ polarization $\left(H_{n} E_{x}\right.$ and $\left.E_{y}\right)$. Yee's mesh is widely used in the FDTD analysis [6] Here, Yoe's iwo dimensional mesh in Finite Difference Time Domain solver is used. The unil 
Yee cell of the two-dimensional mesh for $E$ polarization case is illustruted in Fig. I.

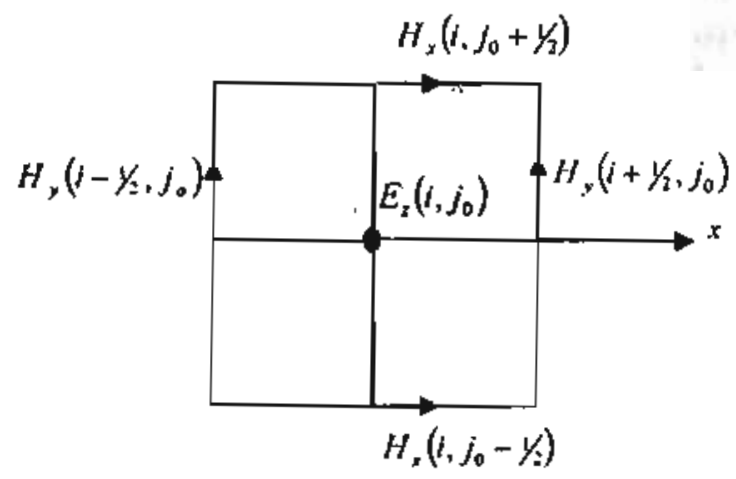

Fig. 1. The unit Yee cell of the two-dimensional FDTD mesh for E polarization case[6].

The continuity conditions are automatically salisficl since; all the transverse field components are tangential to the unit cell boundaries. The following 2-D FDTD time stepping fonmulis constitute the discretization (in space and time) of Maxwell's equations on a discrete Iwo-dincensional mexh in a Cartexian $x$ y. coordinale system lor li polarization calse:

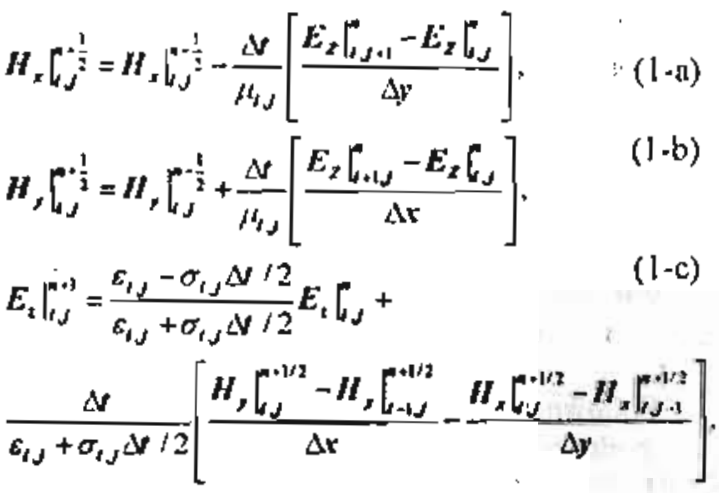

and for $\mathrm{H}$ polarization case

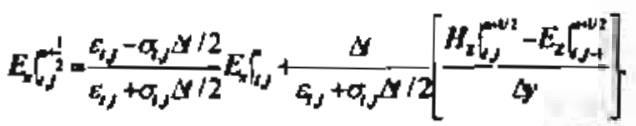

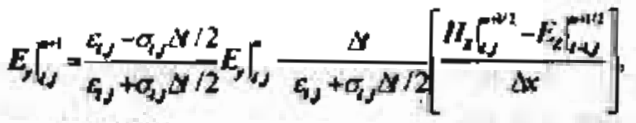

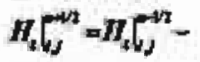

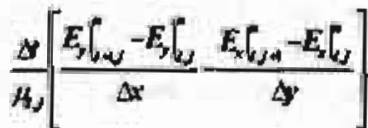

where superscript " indicates the discrete timc stcp, subscripts $i$ and $j$ indicnte the position of a grid point in the $x$, and $y$ directions, respectively. $\Delta t$ is the time incroment, and $\Delta x$, and $\Delta y$ are the space incremuzls between two neighboring grid points along the $x$ and $y$ directions, respectively $\omega$ is the angular frequency, $\mu, \varepsilon$ and $\sigma$ are the permeability, the permittivity and the conductivity of the medium considered.

\section{C- Stability Condition}

For two-dimensional FDTD timestepping formulas, the stability conditions for an orthogonnl case is [6]

$$
\Delta t \leq \frac{1}{c \sqrt{(\Delta x)^{-2}+(\Delta y)^{-2}}}
$$

\section{Methods of Calculating PBG}

\section{A. Band Structure}

When calculating the band structures of photonic crystals, one nalurally chooses a unil cell of lattice as the finite computation domain (13rillsuin zant), and uses the periodic boundary condition, which salislies the Bloch theory [3] th shown in Fig. 2. Therefore, we have the lollowing simple boundary conditions for updaling the fields,

$$
\begin{aligned}
& \vec{E}(\bar{r}+\bar{L})=e^{\operatorname{set}} \bar{E}(\bar{r}) . \\
& \bar{H}(\bar{r}+\bar{L})=e^{\text {at }} \bar{H}(\bar{r}) .
\end{aligned}
$$

where $L$ is the lattica vector.

In FDTD method, all the fields ar obtained in the time domain. However, the dispersion relation (the band structures, guidej modes, elc) of a photonic crystal is a relation between the frequency and the wave vector Therefore, we need to perform a Fouries transform,

$$
u(\omega)=\int_{-\infty}^{+\infty} u(t) e^{i \omega t} d t
$$

where $u$ is one of the field components Unfortunately, the exncl Fourier transfom cannot be obtained since the information abou $u(b)$ lor $1<0$ is not available in our computation, However, one is not interested in the exacl spectral shape of Fourier transform but the peak: of the spectral distribution, which correspond is the localions of the cigen frequencies. Thereforc one can use the following transformation I" obtain the spectrum, 


$$
\begin{aligned}
& u(\omega)=\int_{0}^{N} \|(1) e^{\sec d t} \\
& \approx \sum_{n=0}^{N} n(n \Delta /) e^{\operatorname{mos} \Delta t} \Delta t
\end{aligned}
$$

where $N_{1}$ is the lotal number of time steps. The peaks of the function $u(a)$ are located at the same places as the peaks in the Fourier transform of $u(t)$, and these peaks become higher (more obvious) as $N_{1}$ increases.

One should subtracl the slatic component from the fields so Uhal their lime average is zero. Also, it is not always necessary to calculate the above transformation al all the discretizalion points in the unit cell of Jatlice (the compulation dounain). Onc may choose 100 points randomly and then stm up the spectral aupptitudes al all these points,

$u(\omega)=\sum_{i, j} \mid \sum_{n=0}^{N_{4}}\left(\begin{array}{l}u_{i, j}(n \Delta t)- \\ \frac{1}{n} \sum_{m=0}^{n} u_{t, j}(m \Delta t)\end{array}\right) e^{m+\Delta \Delta^{\prime} \Delta t} \Delta .(7)$

where (i,j) indieales lhe 100 randomly chosen points. Jlic paks of the specinal linetion U(i,j) indicate the locations of the cigen licquencies $\omega$.

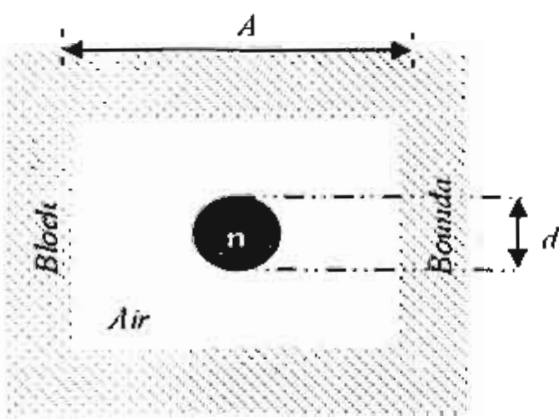

Fig.2. One Unit Cell of square lallicc Photonic cristal structure

\section{Transmission Diagram}

In this melhod, we suppose that i Gaussian pulsc propagates nomally (nomal incidence) to the 2-D photonic crystal. A perfectly malched layer (PML) with the following impedance matching condition [7] is applied to bound the computational window. In the PML, the electric or magnetic tield components are split into two subcomponents (c.g., $E_{z}=E_{z x}+E_{z y}$ ) with the possibility of assigning losses to the individual split rickl components.

$$
\frac{\sigma_{\varepsilon}}{\varepsilon_{o} n^{2}}=\frac{\sigma_{m}}{\mu_{o}}
$$

where $\sigma_{\text {, and }} \sigma_{m}$ are the cloclric and magnelic conductivilies of the PML, respectively, and $\mu$ is Uhe refraclive inder of the adjacent compuling domain, which means that the wave impedance of a PML moiium exactly eguals to that of the adjacent medium in the computing window regardless of the angle of propagation.

The tratusmission is compuled by companing imcident futd transunittod corergy and is given by the following relation [6]

$$
T_{l}\left(\omega_{1}\right)=\frac{P\left(v_{\text {reals }}, \omega_{1}\right)}{P\left(v_{\text {ime }}, \omega_{l}\right)},
$$

where, $y_{\text {un }}$ is a value of $y$ at the very beginuitug ol the dombin atud yiras at lic very end

'Tlice may be mumerical problems computing ironsmission with (9), lor cxmiple unexpectal relloclions. All altentative way is to use if relerence struclure. Then we contuntle flue

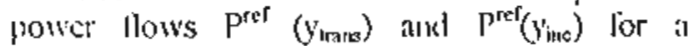
struclure where the subject of inlerest does not inpear in the specilied problem, for crample at waregaide withoul holes. Flen we do the computations once again, will the interesting subjoxl apprening. Now, the trangmission becounts:

$$
r,\left(\omega_{i}\right)=\frac{P\left(y_{\text {roms }}, \omega_{1}\right)}{P^{\text {rof }}\left(y_{\text {rous }}, \omega_{3}\right)} .
$$

[This is the fraction of encrgy that passes durough nn arcil al $y=y$ rrims will and withoul a specilic subjecil.

The diagran of Iransnission of this crystul gives the prestnce of band gaps il cxisl.

'This method also is used for calculating Jic propagation characleristics ol lwo types of pholenic bandgap devices: filter otid splitler.

\section{Defected Structure}

This method is used for ensuring Uic existence of $P B G$ through chlculaling the electric field paltem. If one introduces a line defect (i.e., a waveguide) into a pholonic crystal whjch has a photonic band gap, one car guide light (whose frequencies are wilhin the photonic band gav) fron one location to another since light lias nowlice else to go. 


\section{Nuncrital resulis}

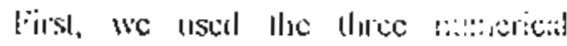

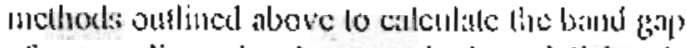
of a [wo-dimensional square lattice or dieleclis sols in air, in which the diclectric "itoms' anc isolnted. The radius of the rod is $\mathrm{R}=0.18 \mathrm{a}(\mathrm{A}$ is the lotlice onstant $A=0.58 \mu \mathrm{m}$ ) [8]. "lito dielectric constant of the rods is $\varepsilon_{\mathrm{T}}=3.4$ as insel in Fig. 3.a. Figure 3.b shows the band struclures of the pholonic cystai for E polarjzations casc, in fis cisc, only', one cell has bocn discrelizul ritl:

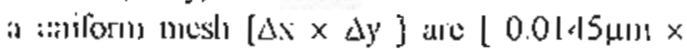
$0.01 / 5$ mh 1, us tune slep $\Delta$ is $0.023586 f s$ anci

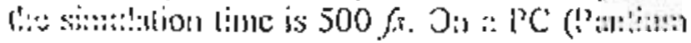

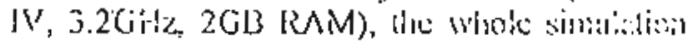

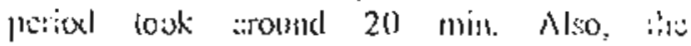
imanision jower spectnin is colchilition $i_{i}$

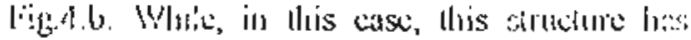

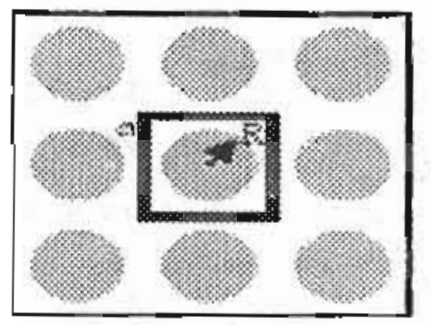

(ii)

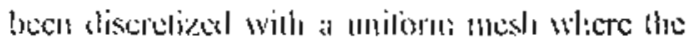

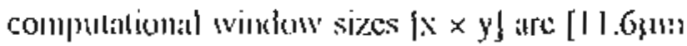
$\times 5.3$ tm ], the time slcp $\Delta /$ is $0.0171002 \mathrm{fs}$ and fle sumulation time is $3000 \mathrm{fs}$. The PML laycis arc assumed to be 50 layers. On a $P C$ (Pantium IV, 3.2GHz, 2GB lQAM), the whole simulation peitod look around 45 min. One can sec from these Figures that there is only large band gap for the $E$ polarization around the nomalized jiefuency 0.34 . Morcover, this is obvious from

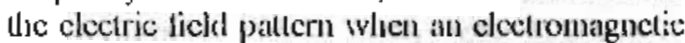
ware propagatcs througl a plotonic crystil mavguide will cxiculin]ly a 100\% lransmission

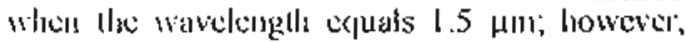
Liere is 1 o propangalion lor wavelengli equat:

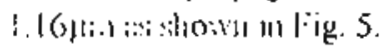

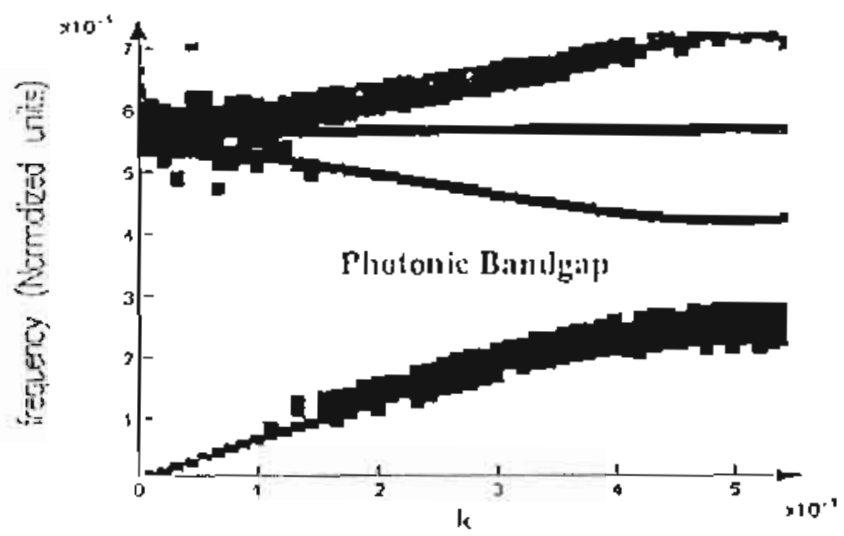

(b)

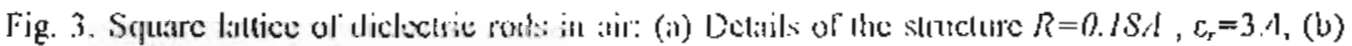
Dispersion diagran lor L' polirizalion cinc.

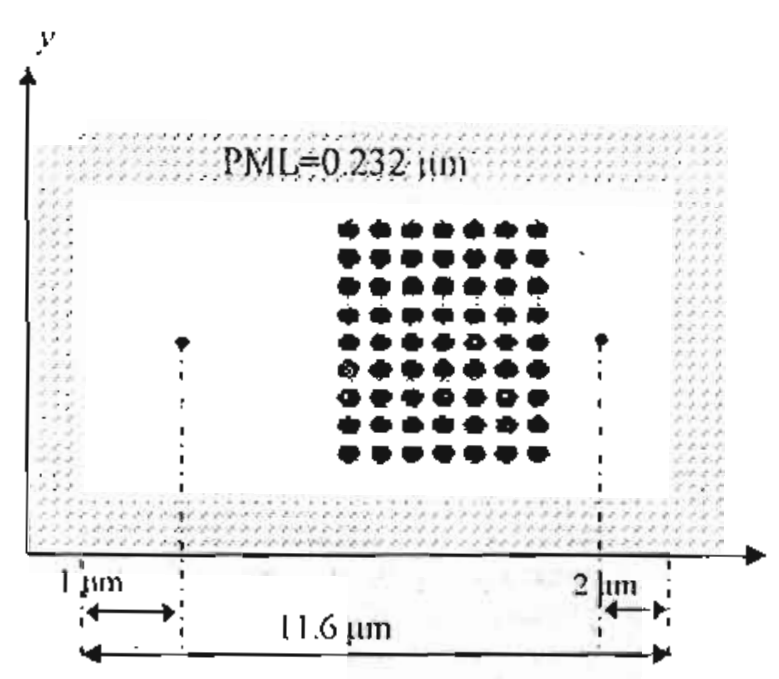

(i)

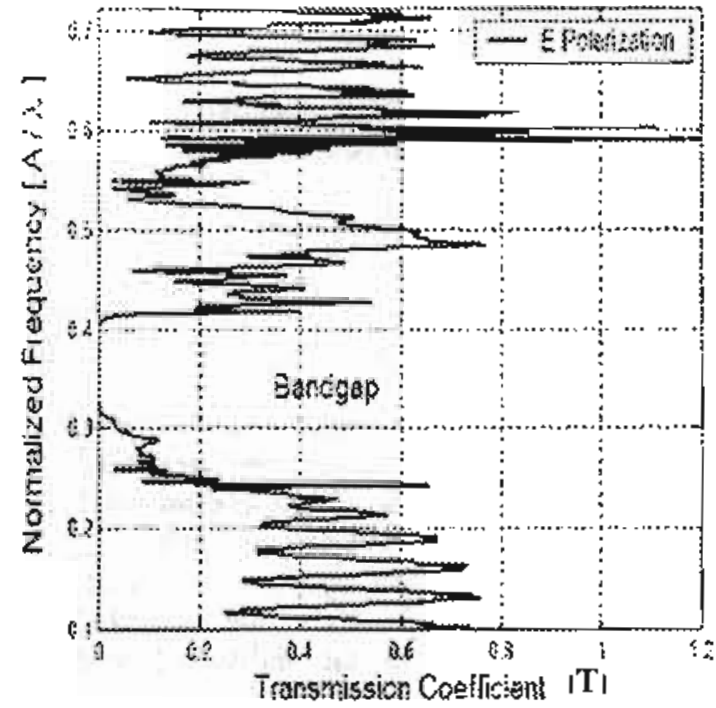

(b)

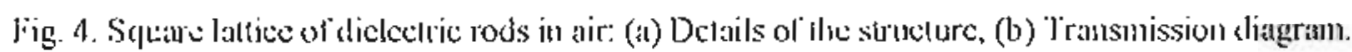




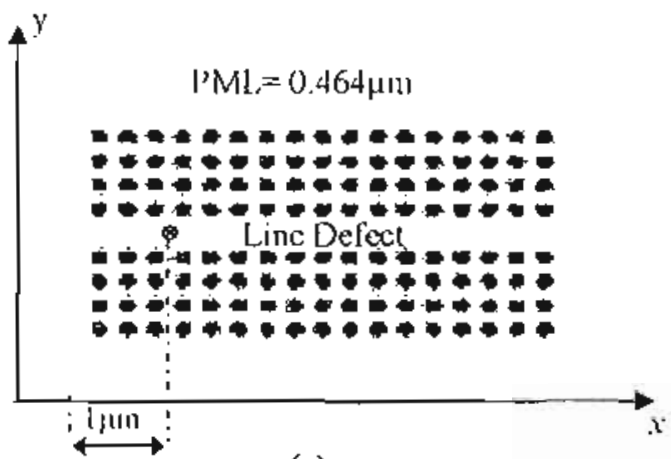

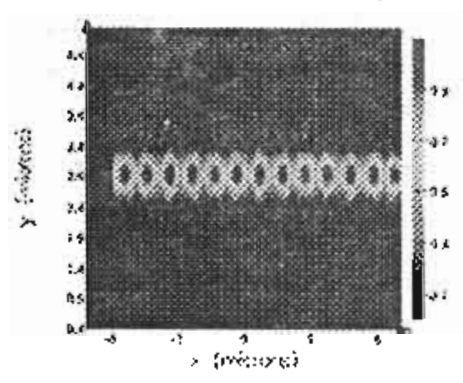

(b) (al)

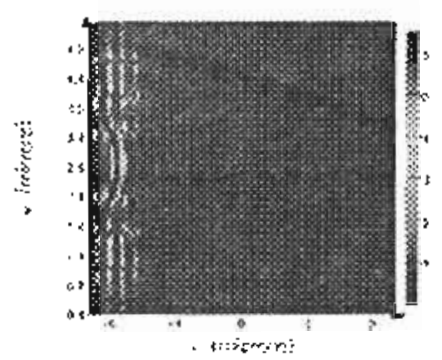

(c)

liig. 5. Delected suructures (a) $\lambda=1.5 \mathrm{~mm}$ (b) $\lambda=1.16 \mathrm{um}$

The itove results help to calculate the Bloch modes of the first Brillouin zone.

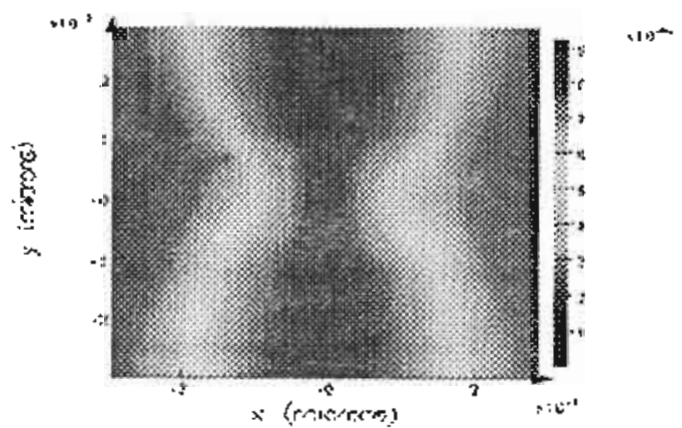

(a)
As shown in Fig. 6. The Blocti modes ane calculated for $1.309 \mu \mathrm{m}$ and $1.736526 \mu \mathrm{m}$, respectively

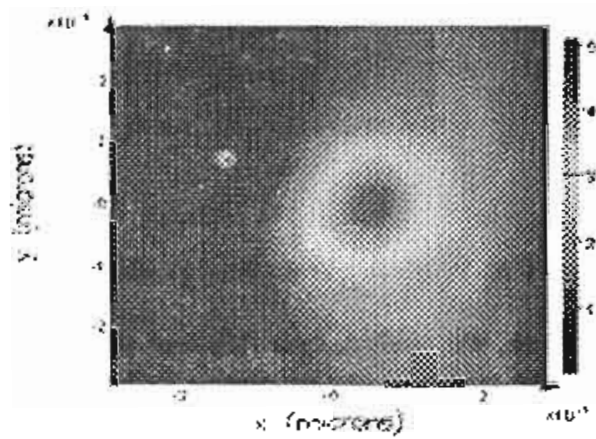

(b)

Fig. 6. Bloch modes (a) $\lambda_{1}=1.309 \mu \mathrm{m}$, (b) $\lambda_{2}=1.736526$ بm.

Next, consider anoticr two-dimensional photonic crustal, a sçuare lattice of diclectric veins, in which the dielectric 'alons' itro connected as insel in Fig. 7. Figure 8 shows the band struclure and transmission dingram for $\mathrm{HI}$ polanization case with hal $\mathrm{vcln}$ width $d=0 . / 20 \mathrm{a}$ [3]. From Fig. 8, one can see thal there is a bind gap for the $H$ polariation around the trejuency $0.350(\omega a / 2 \pi c)$. Therefore, it appears that $E$ polarization band gaps anc favored in a lallice of isolalcd high- $r$, regions, and $H$ polarizalion band gaps are favored in a connected latlice. This is i rule of thumb for photonic band gaps. furthermore, this is obvious lrom the electric ficld paltein when aur elcclromagnetic wave mopragales ulrough a defeclea photonic cryslal structure as demonstrated in Fig. ?.

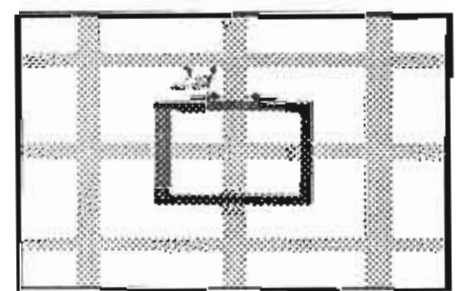

Fig. 7 Square latlice of dielectric veurs in air. The latf vein width is $d=0.120 a$. The dielectric constint of the veins is $\varepsilon=1 / .4$. 


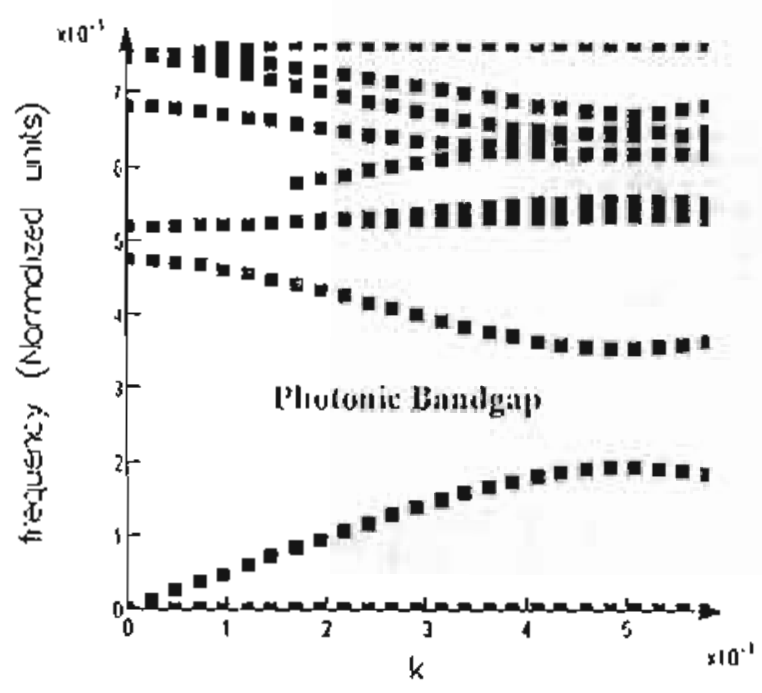

(a)

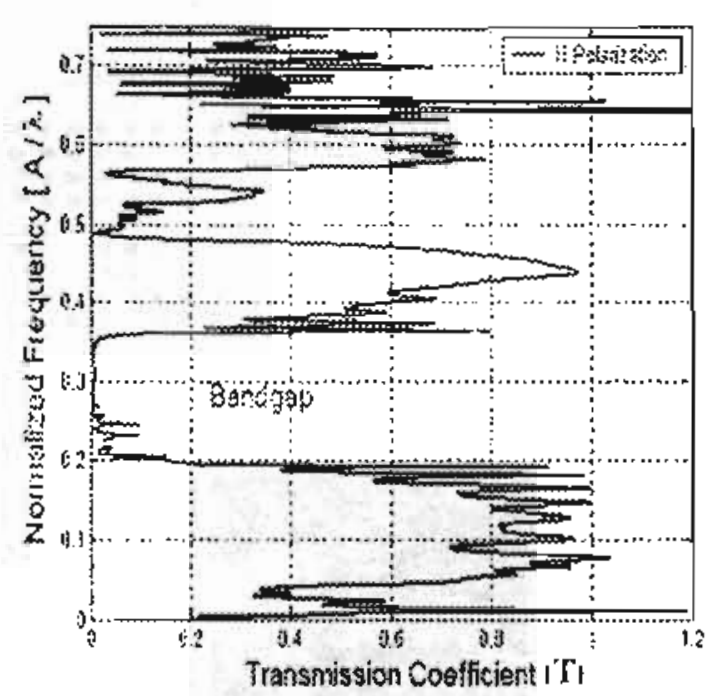

(b)

Fig. 8. Square taluice ol aliclectric veins in air: (a) Dispersion relation for H polarizalion,

(b) Transmission diagram.

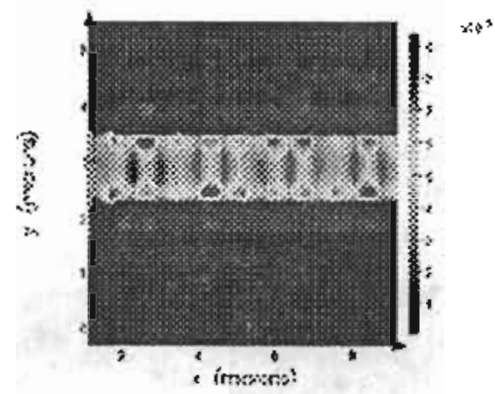

(a)

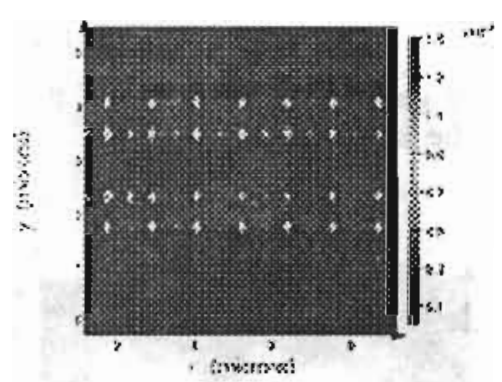

(b)

Fig. 9. Steady state lield profile ol clofectal silluctures at: (a) $\lambda=1.5 \mathrm{um}$, (b) $\lambda=1.16 \mathrm{um}$.

Now, we analyze wo different pholotic crysial circuit components as shown in Figs 10 16 and simulnte those propagation charactcristics. For all eximples presented in conncclion will photonic crystal cinculs in this subscclion, the circuits atc leckl in the fillore andyzed square latlice shown in Fig. 3 .al atnd llic input Gaussian pulse are the same at contral wh velength 1.55 t.m and led al point $P$.

First, we consider different mumbess of micro-cavities coupled to straight waveguides is sllown in Fig. 10.a and Fig 11. The computational window sizes $[x \quad x \quad y]$ alc [53.94 $\mu \mathrm{m} \times 6.85125 \mu \mathrm{m}]$, the lime stcp $\Delta \mathrm{t}$ is $0.0641259 \mathrm{fs}$ and the simulation time is $5000 / \mathrm{s}$. '[le PML layers are assumed to be 20 laycis. On a PC (Tantiun IV, 3.2Gl-L, IGB RAM), the whole simulation period look arome 30 min.
From the Iransmission characleristics shown in Fig. 10.b, it is clear that, with tl:s increase of the number of circular rots in the center of the PC waveguide, there is a decrense of the anount of the transmitled power to at proinl $P$ ? in lle slluclure shown in Fig. 10.n.

On the ofler land, inserting a single cavily can produce an optical filter with a slanp transmission resonamce. Fig. 12.a shows that, the single cavity should be held only in the centre of the circular rods to achieve fitter with high sharp transmission resonance. The results obtained by the finite element method are presented in reference $|8|$ and excellent agroement is oblained. Varying the width of the single cavity will changes the frequency resonant point as inset in Fig. 12.b. Moreover, Fig. 13 shows that, increasing the number of micro-cavilies will increase the bandwidtr ol' the l'C liticr. 


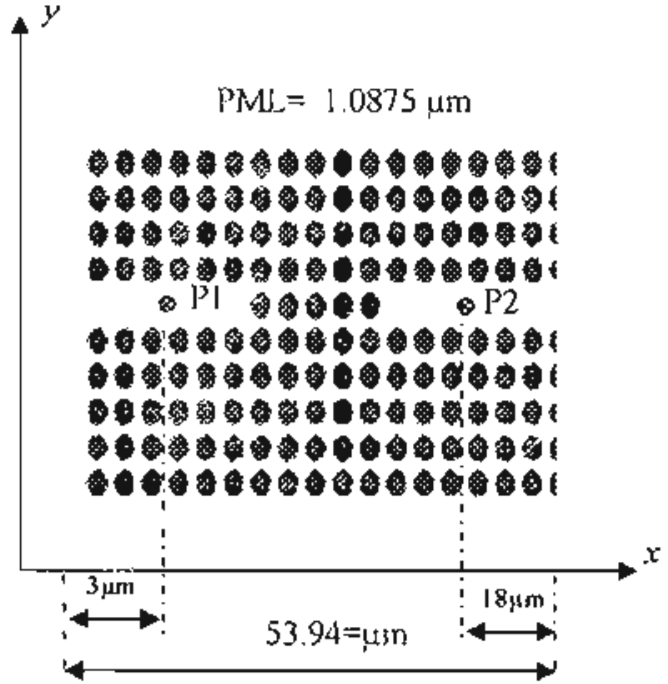

(a)

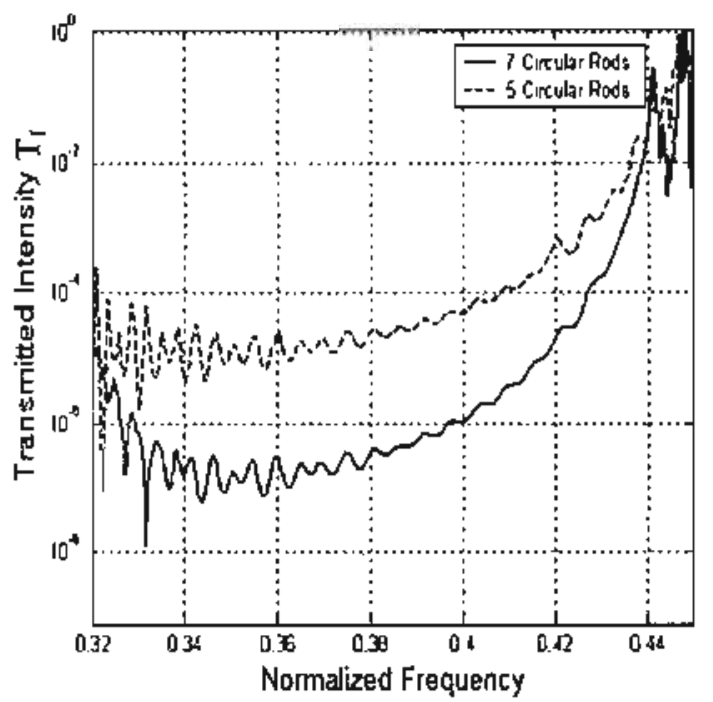

(b)

Fig. 10. Squarc lallice of diclectre sods in alr with line delect: (a) Structure geomely, (b) Transmission djagram.

$+$

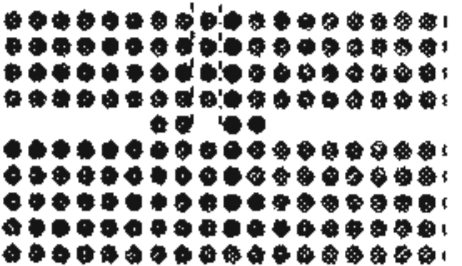

(a)

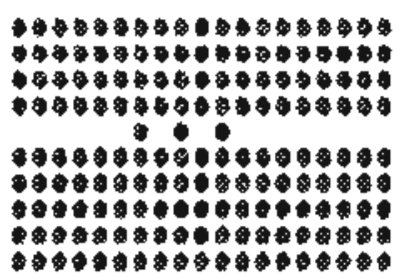

(b)

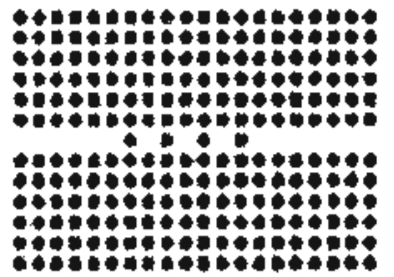

(c)

Fig. 1 1. Plyotonic erystal liller wulh: (a) Single cavily, (b) Double cavitics, (c) "lemible cinvities.

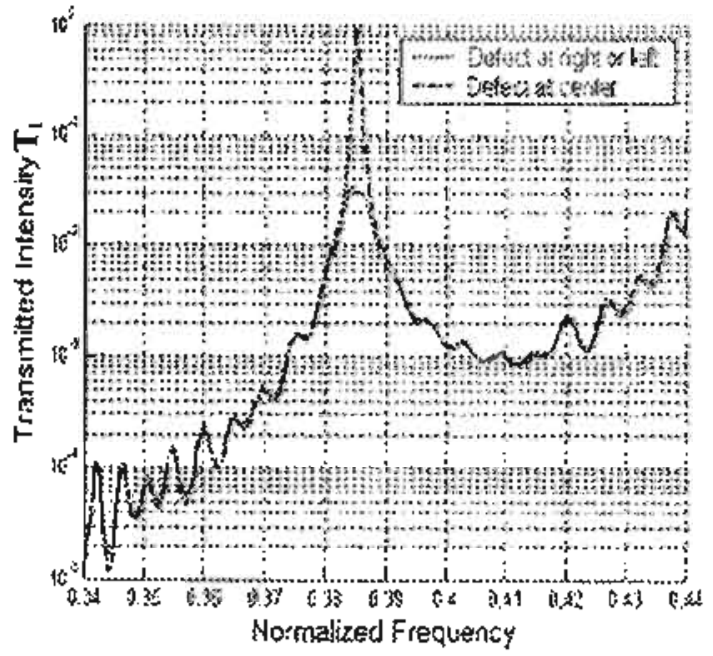

(a)

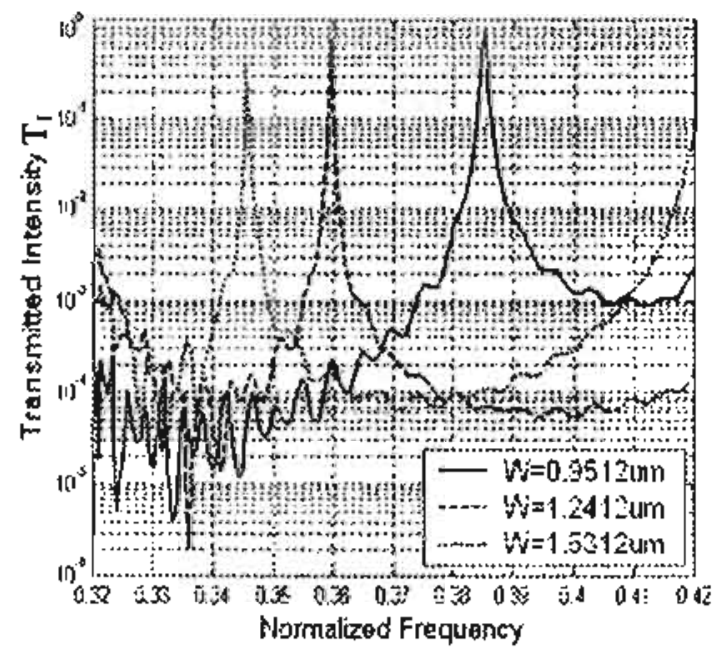

(b)

Fig. 12. Propagation Characteristics for PC Filler with: (a) Single cavity lilter, (h) Propagation chancleristics for l'C filer with single cavily versus ditherchl delect widus. 


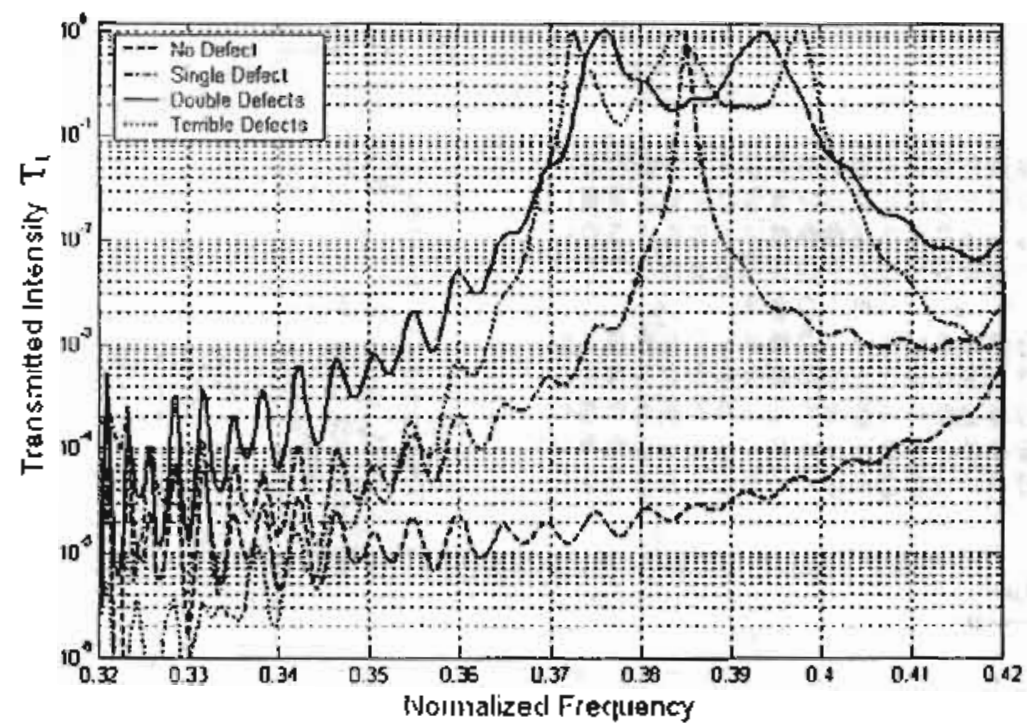

Fig. I 3. Comparison between l'C lïllers will dillerent number ol cavitics.

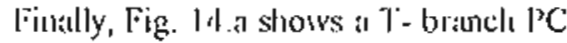
spliller. The compulational window sizes $[x \times y]$ are $[53.94 \mu \mathrm{m} \times 11.47 \mathrm{l} \mu \mathrm{m}]$, the linc slcp $\Delta \mathrm{l}$ is $0.0645129 / \mathrm{s}$ and the simulation time is $1800 / \mathrm{s}$. The PML layers are assumed to be 20 layers. On a PC (Pantium IV, 3.2G[-J\%, IGB RNM), the whole simulation period took around one hour. From the calculated propagation characteristics shown in Fig. 14.b, the high transmission is observod at nomalized frepuency ranges from 0.386 to 0.403 . Also the two ports of the PC

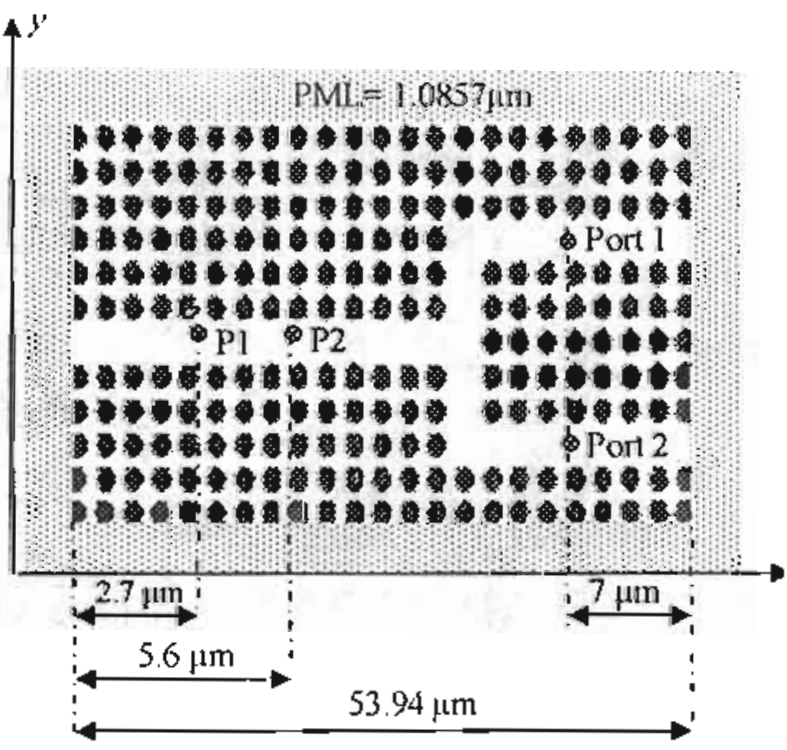

(i) splitter lave obtained approximately the same anount of the transmitled inlensity over the same considered liequency range. On the other land, the transmission properties of splitters slown in Figs. 15 and 16 are also high but, each port lias chlained a different amount of trausmitlex intensity than the other for specific values of frequencies. This device could be used lor designing a multiplexer consisting of such a splitter followed by a filter in each arm tuned to llic concsponding frequency.

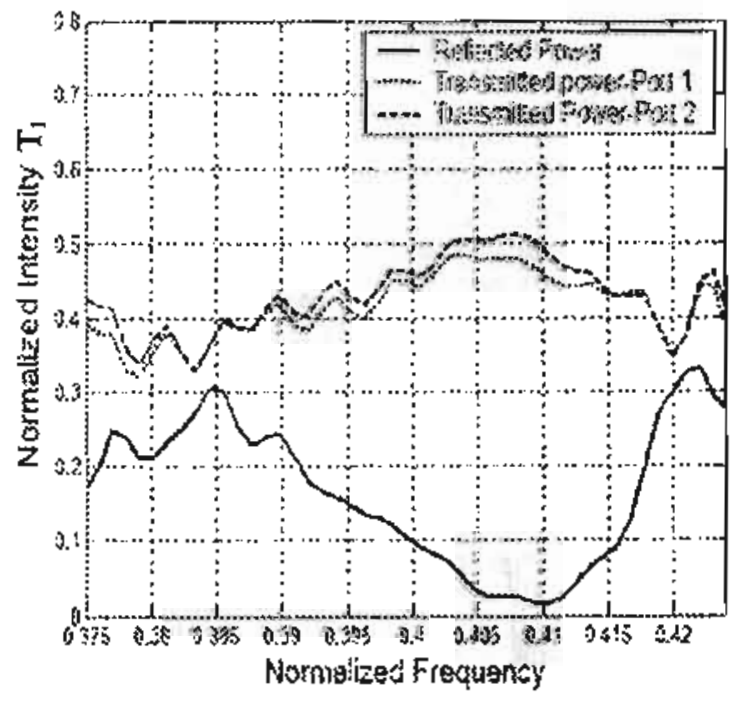

(b)

Fig. 14. PC splitter of dielectric rods in air: (a) Structure geometry, (b) Propagation characteristics. 


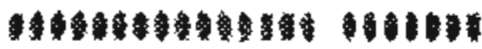

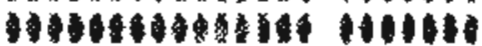

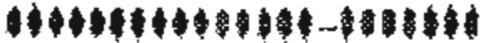

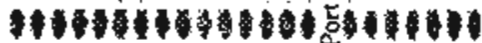

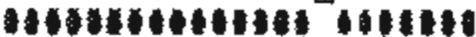

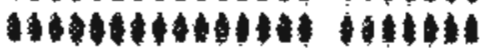 Input $\mathrm{P}^{\mathrm{O}} \mathrm{ort}$ \\ Port 2

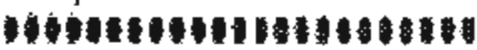

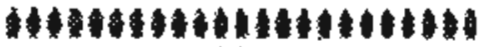

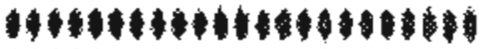

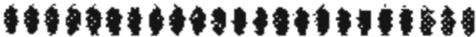

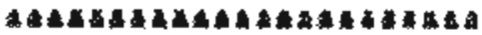

(a)

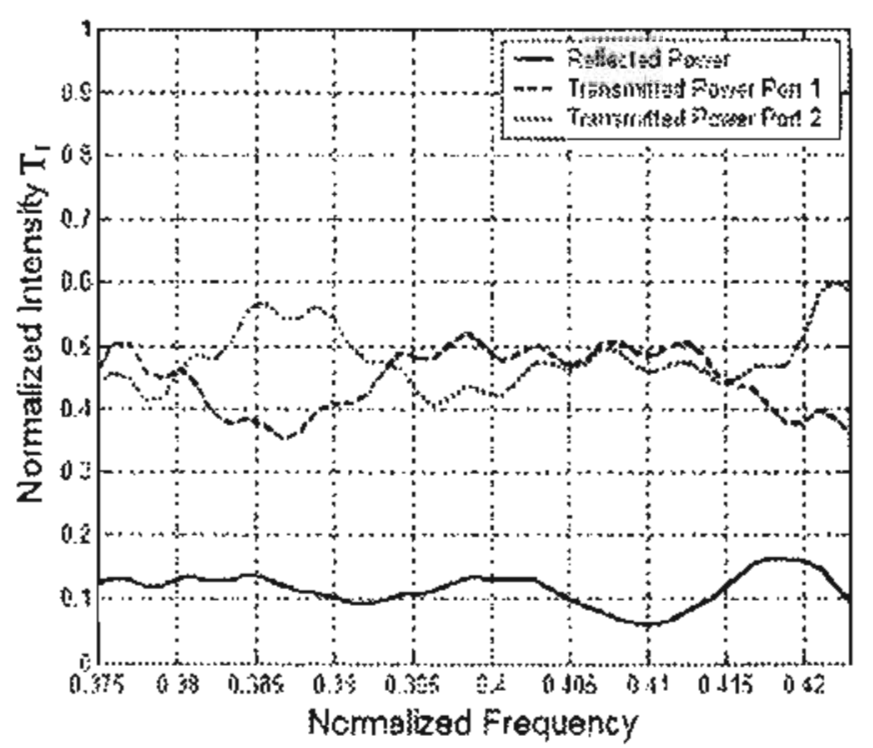

(b)

Fig. 15. PC splitter of dielectric rods in air: (a) Struclure geomelsy, (b) Propagalion characteristies.

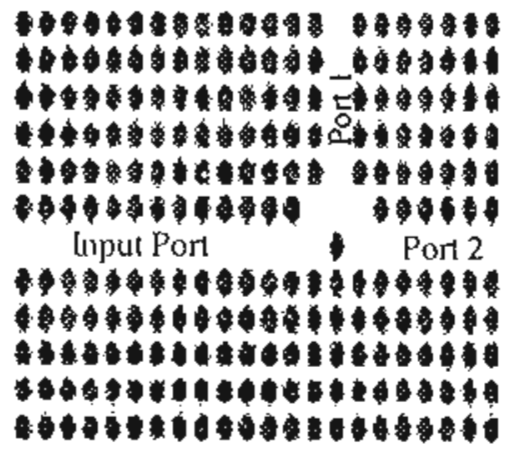

(a)

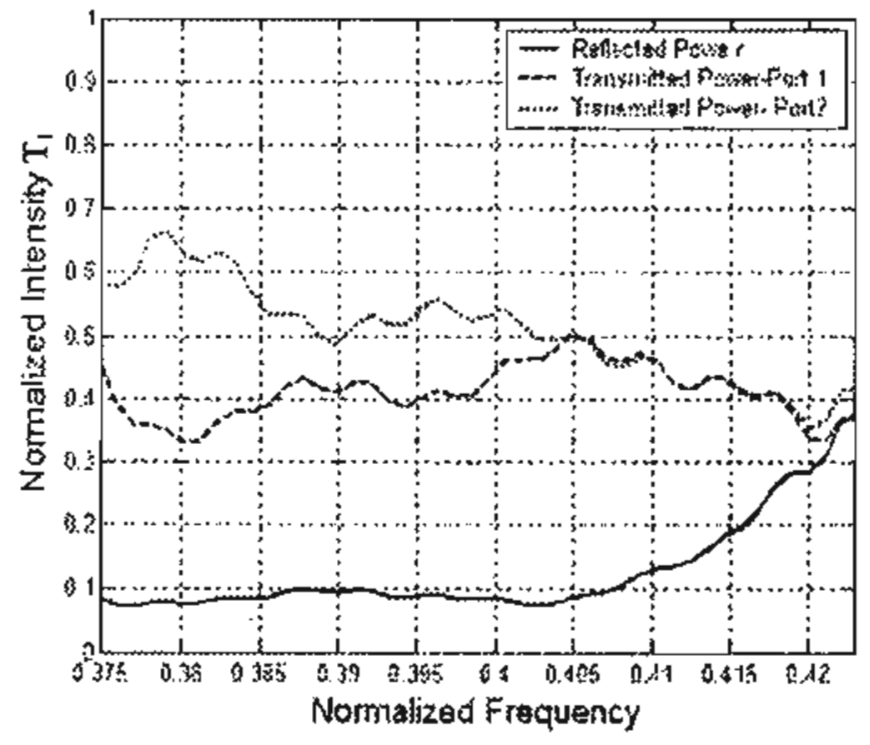

(b)

Fig. 16. PC splitler of dielectric rods in air: (a) Struclure geomelry, (b) Propagation characteristics. 


\section{Conclusion}

[inile diJerence Time Domain algorithm incomorated with Bloch periodic or pertectly matched layer absorbing boundary condition is formulated for the calculating the band gap of different latices of 2-D photonic erystal structures. To validate the progarn, comparison wilh the finjte element method in frequency domain is obtained and showed an excellent agreement. Furthermorc, two different photonic crystal circuit components were simulated and their fascinasing properties were presented.

\section{References and Web Links}

1. Iıllp//www azonano.com/Delails asp? Arljc] eID $=1256$

2. litp://www.public jastate edw/cmpexp/grou ps/holpbghtiml

3. Min Qiu, Compulational methods for the analysis and design of Photonic bandgap slructures, Ph. D., Royal Institulc of 'Tcchnology, Stockholm, 2000.

4. Joen I. Kim , Analysis and applications ol microstructure and holey optical nibers, P'l. D. Virginia Stale Universily, 10 Sepl. 2003.

5. J. M. Lourtioz, H. Benisty V. Berger, J. M. Gerard D. Maysire, and A. Techelonkow, Photonic Crystals lowards Nanoscale Photonic Device, Springer Verlag Berlin [-Tcidelberg, 2005.

6. Tommy Sundstrom, Analysis of Photonic Crystal Waveguides by the usc of FDTD with Regularization, KTH Numerical Analysis and Computer Science, Stockholm, 2004.

7. Chin-Ping $\mathrm{Yu}$ and Hung-Chun Chang. "Yeemesh-based finite difference eigerunode solver with PML absorbing boundary conditions for optical waveguides and photonic crystal fibers," Opt. Express, Vol. 12, No. 25, pp. 6165.6177, 13 December 2004.

8. Masanori Koshiba, Yasuhide Tsuji, Masnfumi Hikari, "Time Domain Beam
Propigation Melhod and Its Applicalion to Photonic Ciystal Circuits," IEEE Joumal of Lightwave Technol., Vol. 18, No. I, pp. 102-110, January 2000. 